\title{
STK32B wt Allele
}

National Cancer Institute

\section{Source}

National Cancer Institute. ST K32B wt Allele. NCI Thesaurus. Code C158548.

Human ST K32B wild-type allele is located in the vicinity of 4p16.2 and is approximately $450 \mathrm{~kb}$ in length. This allele, which encodes serine/threonine-protein kinase 32B protein, plays a role in limb development. Deletion of the gene is associated with the autosomal recessive skeletal dysplasia, Ellis-van Creveld syndrome. 